\title{
EMPIRICAL REVIEW ON THE REGULATIONS, INTEGRATIONS OF WORKS AND LOCAL AUTHORIZATION AND THE ATTRIBUTES OF CRITICAL SUCCESS FACTORS AND CONSTRUCTIONS DELAY OF THE ROAD PROJECTS IN OMAN
}

\author{
Suleiman Said Al Hinai \\ PhD Student \\ Faculty of Business and Accountancy \\ University of Selangor, Malaysia \\ E-mail: s.alhinai36yy@gmail.com \\ Dr. Abul Bashar Bhuiyan \\ Associate Professor \\ Faculty of Business and Accountancy \\ University of Selangor, Malaysia \\ E-mail: bashariuk@gmail.com \\ Dr. Setyawan Widyarto \\ Associate Professor and Dean \\ Centre for Graduate Studies \\ University of Selangor, Malaysia \\ E-mail: swidyarto@unisel.edu.my
}

\begin{abstract}
The prime aims of the study to investigates of empirical articles and reviewed on the moderating effects of the regulations, integrations of works and local authorization on the attributes of critical success factors and constructions delay of the road projects in Oman. The study used the empirical literature from the all relevant online sources and data 231 based as many as possible. The findings short listed the consultant related factors, the contractor related factors, designed related factors, client related factors, labor related factors, material related issues, equipment related issues respectively. Moreover, study also summarized that there are moderating effects of the regulations, integrations of works and local authorization on the attributes of critical success factors and constructions delay of the road projects in Oman. The present study recommends doing a conclusive investigation on the above literature gap by real data and justifying above review relationship of moderating effects of the regulations, integrations of works and local authorization on the attributes of critical success factors and constructions delay of the road projects in Oman.
\end{abstract}

Keywords: Critical Success Factors, Road Constructions Delay, Oman. 


\section{INTRODUCTION}

The causes of delays are the primary constraints to achieve the project objectives in the developing world. (Abdel Khalek, Aziz, \& Abdeen, 2018). Alamri, N., et al. in 2017. Moreover, delay causes, impacts on the road constructions projects in the Sultanate of Oman Oyegoke, A. S. and N. Al Kiyumi in 2017. However, the evaluation of the progress reports on the road projects constructed during the period 2011-2015 in Saudi Arabia concluded that delays are extensive: the average ratio of planned contract duration to the actual completion time is $58.24 \%$, ranging from $2 \%$ to $172 \%$ Mahamid, I. in 2017. Empirical findings also concluded that causes of delay have different types of construction, different countries, different periods and different number of causes of delay and groups of delays. Therefore, it is important to investigate and analyze the causes of delays in road construction (Aziz \& Abdel-Hakam, 2016; Elawi, Algahtany, \& Kashiwagi, 2016). Moreover, studies also summarized about road construction is considered as one of the most important industries where are exposed to time and cost overrun or both (Bekr, 2015)

Moreover, studies indicated that owners rank poor communication among project participants as the top severe factor affecting the performance in construction projects, followed by poor labor productivity and poor planning and scheduling, respectively. However, contractors' point of view, concluded the most severe factor is payments delay, followed by escalation of material prices and poor labor productivity, respectively. In case of consultant's issues, there are top three affecting by poor management of planning, scheduling, site and payment delays respectively (Mahamid, 2016). In the same way, causes of project delays was experiencing delays from 50\% to $150 \%$ in KSA. Alzara, M., et al. in 2016 However, identified the cost and time overrun allocated for this type of road projects and cause critical problems for both the developer and the contractor in Jordan, which. Al-Hazim, N. and Z. A. Salem in 2015. Another study discovered causes of delays in road construction projects considered as investments in an unpredictable market in Lebanon. Tarhini, A., et al. in 2015. Moreover, road construction projects delay and causes are differ from one country to another even within the same geographic location (Emam, Farrell, \& Abdelaal, 2015; R. Hasan, Suliman, \& Malki, 2014). However, Jarkas, A. M. and J. H. Younes in 2014 revealed about the delays in construction projects are global phenomena and the State of Qatar is no exception. Moreover, It is the very crucial and important issues to explore on the key determinants of productivity, their relationships and the problem categories responsible for delays of the road construction industry in Oman. However, Studies also summarized that owners, consultants, contractors, and foremen/worker roles and responsibilities, especially of their competencies of professionalism, fairness in financial transactions, incompetent skill of supervision materials handle, and designing accordingly (Emam et al., 2015). In Jordan construction industry is a major player in the economy, generating both, employment and wealth. However, many projects experience extensive delays and thereby exceed initial time and cost estimates (Sweis, Sweis, Abu Hammad, \& Shboul, 2008)

There are numerous issues and challenges are facing for road constructions industries in all over the countries, especially, improper contract management and some other unexpected events, so many claims and disputes are raised by the owner, consultant, and contractor each other's. They are usually accompanied by cost overruns. Moreover, it is debilitating effect on clients, contractors, and consultants in terms of growth in adversarial relationships, mistrust, litigation, arbitration, cash-flow problems, and a general feeling of trepidation towards each other. Nevertheless, it has revealed also caused and effects as time delay in construction projects, 
size or its experience, Large to small construction firms display greater tendency to time delay, few found that tendency of time delay increases with the experience of construction firm and others found the converse. There is still debate to summarized influential caused and its effects on the road constructions industries. Moreover, there is unique study has explored yet to summarized the critical factors in the area of Arab counties. Therefore, the present study taken initiatives to evaluate the current status delay level of the constructions of road as well as also will identify the critical success factors especially the contactor, owner, consulted, designed, client, manpower and resources, material and suppliers and equipment related attributes caused delay of constructions of road in Oman. Furthermore, study also will fill-up literature gap by applying of government regulations, departmental integrations of works and local authorization weather there is moderating effects of the on the attributes of critical success factors and constructions delay of the road projects in Oman.

\section{BACKGROUND OF THE STUDY}

\section{Issues Delay of Road Construction in Oman}

Empirical findings revealed that the construction industries in the Gulf cooperative countries are facing severe delays due to management, finance, human resources and Empirical findings have shown that the construction industry in Gulf cooperative countries faces severe delays due to governance, finances, human resources and design problems, planning delays due to project management, lack of experience of the contractor, and the order of changes due to owner shortage and lack of materials and equipment are in significant problem for delays in project delivery in Oman. In the same way, investigation revealed that the causes of delays in Dam projects in Oman. There are 60 causes of delay were integrated among Client, Contractor, Consultant and External Factors. The results reveal, based on Pareto's law of 80/20, that the top causes behind the delays of Dam construction projects in Oman are: severe weather conditions, change orders, uncertainty in ground condition, poor site management, executive bureaucracy in client organization, feasibility study did not cover all aspects, mistakes in soil investigation, natural effects during construction work, difficulty of defining project requirement, slowness of decision making process, delay of obtaining approval from the different government authorities, and land acquisition (Alamri, Amoudi, \& Njie, 2017).

Moreover, Gebrehiwet, T. and H. Luo in 2017 investigates the typical causes of delay at different stages of construction and its effect in the Ethiopian construction projects. So from the overall, the influential causes of delay investigated are corruption, unavailability of utilities at site, inflation/price increases in materials, lack of quality materials, late design and design documents, slow delivery of materials, late in approving and receiving of complete project work, poor site management and performance, late release budget/funds, and ineffective project planning and scheduling successively (Gebrehiwet \& Luo, 2017). However, Oyegoke, A. S. and N. Al Kiyumi in 2017 identified the causes, impacts and mitigations of delay in megaprojects in the Sultanate of Oman. There are 53 questionnaires were received and analysed using the relative importance index (RII) method. The five most frequent causes of delay in the Sultanate of Oman, in rank order, are: selection of the lowest bid, instead of best bid for the client (RII: 0.698); the financial condition of the main contractor (RII: 0.664); delay in decision-making by the client (RII: 0.656); and poor construction planning by the main contractor (RII: 0.649). Also, the findings indicate that extra cost (RII: 0.754) and project time overrun (RII: 0.724) are the most significant effects of the delay in the Oman megaprojects. The use of experienced contractors and consultant (RII 0.675), efficient construction planning by the main contractor and effective 
site management and supervision (RII: 0.667) are essential mitigation methods of construction delay in Oman megaprojects. The study recommends three-part novel solutions to mitigate delay in the Oman construction industry (Oyegoke \& Al Kiyumi, 2017). Moreover, Alzebdeh, K., et al. in 2015 examines interpretive structural modelling (ISM) as a viable technique for modelling complex interactions among factors responsible for cost overruns in construction projects in the Sultanate of Oman. There are four factors were found to be at the root of cost overruns: instability of the US dollar, changes in governmental regulations, faulty cost estimation, and poor coordination among projects' parties. Taking appropriate actions to minimize the influence of these factors can ultimately lead to better control of future project costs. Thisstudy is of value to managers and decision makers because it provides a powerful yet very easy to apply approach for investigating the problem of cost overruns and other similar issues (Alzebdeh, Bashir, \& Al Siyabi, 2015).

However, lack of professionalism, fairness in financial transactions, incompetent supervisors, lack of materials and incomplete drawing have been found as the top five factors in productivity. management, people, cooperation, health and safety, logistics, involvement, operational activity, authority, quality and financial conditions (Bierman, O'donnell, Burke, McCormick, \& Lindsay, 2014). In the same way, other studies examined the causes of delay in construction projects in oil and gas processing facilities in Oman and serves as a case study for the Gulf Cooperation Council (GCC) countries. The survey results showed a high degree of agreement among the perceptions of project stakeholders, clients, contractors, and consultants on the causes of project delay, and there is no evidence to suggest that the causes of project delay differ significantly according to organization size or organizational ownership. Moreover, seven factors were identified as the major causes of project delay (Ruqaishi \& Bashir, 2013)(Alnuaimi, Taha, Al Mohsin, \& Al-Harthi, 2009).

\section{METHODOLOGY OF THE STUDY}

As study aims to investigate existing available literature for determining of relevant factors that have cause and effects on the delay of road construction industry in Oman. Therefore, the study uses available sources of existing literature based on the four main keywords 'critical success factors and road construction delay in Oman', departmental integrations of works on the attributes of critical success factors and constructions delay of the road projects in Oman 'effects of the local authorization on the attributes of critical success factors and constructions delay of the road projects in Oman " to ensure relevant critical success factors especially the contactor, owner, consulted, designed, client, manpower and resources, material and suppliers and equipment related attributes caused delay of constructions of road in Oman.

\section{EMPIRICAL REVIEW FINDINGS}

The present study summarized and short listed of the factors in the two categories such as internal and external factors have caused to be influenced to delay of road constructions in the Arab regions especially in Oman.

\section{Contactor Related Attributes on the Delay of the Road Construction}

Hamontree, C., et al. in 2018 exploed the list of road construction delay causes gathered from literature having different countries. The study indicates that the 5 top factors affecting road construction delays are: incomplete drawings, lack of equipment efficiency or financial status of contractors, delay in relocating existing infrastructure structures, less of project engineer 
experiences, and delay in relieving environmental impact, respectively (Hamontree, Thapanont, Santi, \& Pruethipong, 2018). Mahamid, I. in 2017 identified factors were ranked according to their levels of severity, frequency, and importance. Results indicated that the top five important factors affecting schedule delay in road construction projects are: improper planning, poor labor productivity, additional works, rework, and lack of contractor experience. The study concluded that the main effects of schedule delay in road construction projects as assessed by contractors are: cost overrun, disputes, arbitration, litigation, and poor quality (Mahamid, 2017).Oyegoke, A. S. and N. Al Kiyumi in 2017 identified the five most frequent causes of delay in the Sultanate of Oman, in rank order, are: selection of the lowest bid, instead of best bid for the client (RII: 0.698); the financial condition of the main contractor (RII: 0.664); delay in decision-making by the client (RII: 0.656); and poor construction planning by the main contractor (RII: 0.649). Also, the findings indicate that extra cost (RII: 0.754) and project time overrun (RII: 0.724) are the most significant effects of the delay in the Oman megaprojects. The use of experienced contractors and consultant (RII 0.675), efficient construction planning by the main contractor and effective site management and supervision (RII: 0.667) are essential mitigation methods of construction delay in Oman megaprojects. The study recommends three-part novel solutions to mitigate delay in the Oman construction industry (Oyegoke \& Al Kiyumi, 2017).

Santoso, D. S. and S. Soeng in 2016 analyzed factors on the list were land acquisition, award of project to lowest bidder, equipment breakdowns, poor site arrangement, management and supervision, unexpected ground condition and terrain, low quality of the contractor human resources, late progress payments, and low productivity of labor. Recommendations to manage the delay factors were presented. Significant relationships between the delay factors and the three project objectives also were observed and discussed (Santoso \& Soeng, 2016). Shah, R. K. in 2016 investigated the causes of delays and cost overruns in construction projects in Australia, Malaysia and Ghana. However, there are reasons for delays for road construction projects, especially wrong planning of contractors, poor construction site, insufficient experience with contractors are the most influential factors in Malaysia (Shah, 2016). Bagaya, O. and J. Song in 2016 identified the most frequent, severe, and important causes of schedule delays affecting financial capability of the contractor, financial difficulties of the owner, equipment availability of the contractor, slow payments for completed work, and poor subcontractor performance by the contractor. A comparison of the causes of schedule delays in 11 countries to validate the results of the study showed that financial capability of the contractor was not only the most encountered factor in delays for Burkina Faso's construction industry, but also appeared in many other Asian and African countries (Bagaya \& Song, 2016). Bekr, G. A. in 2015 summarized The 65 causes compiled through the literature review and the pilot study were classified into four groups (client related, contractor related, consultant related and external factors) (Bekr, 2015). Moreover, there several studies have the semilar result and support with above review findings accordingly (Rahman, Lee, \& Ha, 2014), (Mahamid, 2013), (Rafieizonooz, 2012), (Albogamy, Scott, \& Dawood, 2012). (Pourrostam \& Ismail, 2012), (Pathiranage, 2011), (Enshassi, Al-Najjar, \& Kumaraswamy, 2009)(Toor \& Ogunlana, 2008). (Assaf \& Al-Hejji, 2006).

\section{Owner Related Attributes on the Delay of the Road Construction}

Guida, P. L. and G. Sacco in 2019 analyzed of schedule delays is a traditional problem in almost any project of some dimension and complexity. Assessing schedule delays and allocating them to responsible parties and activities is a sensitive problem in project management. In client-supplier, i.e. owner-contractor relations, the schedule delays represent a very important issue, often 
escalating into claims and undermining the commercial outcome of the whole project, involving lengthy negotiations and juridical cases, tracing to responsibilities and financial compensations. (Guida \& Sacco, 2019). Hamontree, C., et al. in 2018 exploed that the delay in construction project is an important issue in construction management. This is because delay will cause negative impacts on both the owner and the contractor. For owner, it will lead to the late opening of new road. For contractor, it will cause extra operating cost. In this paper, therefore, the causes of delay in road construction projects are researched (Hamontree et al., 2018). Another study done by Islam, M. S. and B. Trigunarsyah in 2017 explored factors, delay in progress payment by owner, contractors' cash flow problem, improper planning and scheduling, poor site management, and change order by (Muhammad Saiful Islam \& Trigunarsyah, 2017). (Mohammad Saiful Islam, Trigunarsyah, Hassanain, \& Assaf, 2015), (Bekr, 2015), (Mohammad Saiful Islam et al., 2015), (Bierman et al., 2014), (Cristóba, 2014), (Alnuaimi \& Mohsin, 2013), (Albogamy et al., 2012), (Enshassi et al., 2009), (Al-Najjar, 2008), (Assaf \& Al-Hejji, 2006).

However, Bagaya, O. and J. Song in 2016 identified the most top five most important delay factors were ranked as follows: financial capability of the contractor, financial difficulties of the owner, equipment availability of the contractor, slow payments for completed work, and poor subcontractor performance by the contractor (Bagaya \& Song, 2016). Moverover, Elawi, G. S. A., et al. in 2016 identifies 10 risk factors were identified and were grouped into four categories. Average delay in infrastructure projects in Mecca was found to be $39 \%$. The most severe cause of delay was found to be the land acquisition factor. This highlights the critical land ownership and acquisition issues that are prevailing in the city. It is concluded that the majority of project delays were caused from the owner's side as compared to contractors, consultants, and other project's stakeholders (Elawi et al., 2016). Moreover, there several studies have the semilar result and support with above review findings accordingly (Mohammad Saiful Islam et al., 2015), (Bekr, 2015), (Mohammad Saiful Islam et al., 2015), (Bierman et al., 2014), (Cristóba, 2014), (Alnuaimi \& Mohsin, 2013), (Albogamy et al., 2012), (Enshassi et al., 2009), (Al-Najjar, 2008), (Assaf \& Al-Hejji, 2006).

\section{Consulted Related Attributes on the Delay of the Road Construction}

Alamri, N., et al. in 2017 investigate four main categories: Client, Contractor, Consultant and External Factors. The collected data was then analysed statistically and ranked according to its significance (Alamri et al., 2017). Moreover, Atout, M. M. in 2016 summarized literature about the Construction projects in Gulf rejoin presents particular conditions in which the consultant of the project has to concentrate during each phase of design to ensure that it will be accomplished on time, for example, the unrealistic of project duration, foreign designers and consultants, unusual growth of construction industry, the exceptional features of architectural details in the design of projects, and international consultant establishments, firms and office. Based on above literature this paper investigates the main causes of the delays contributed by the projects designers and consultants by representing their roles and responsibilities to hand over the projects on time. The outcome and the results of the study is prepared based on the designed questionnaires and interviews conducted with many consultants and designers intended to identify the causes of delays projects in Gulf region from the viewpoint of the designers. In addition, the required preventive actions of the designers are studied to avoid any impacts on the progress of the project. The study investigates other factors from the client side, contractor side and the appointed project manager might affect the consultant performance on the project (Atout, 2016). Aziz, R. F. and A. A. Abdel-Hakam in 2016 Analyzed represents consultants, contractors 
and site as well as design engineers with the exclusion of the owner who represents the government in road projects as a party. Revealed the results of serious relationship between campaigns and groups between contractors and site / design engineers and between consultants and site design engineers and a fairly low correlation between contractors and advisors (Aziz \& Abdel-Hakam, 2016). Bagaya, O. and J. Song in 2016 identified the most frequent, severe, and important causes of schedule delays affecting public constructions projects in Burkina Faso to enhance the managerial capability of project managers. This research was conducted by questionnaire survey to solicit the causes of schedule delays from 140 Burkinabé experts (clients, contractors, and consultants) (Bagaya \& Song, 2016). Elawi, G. S. A., et al. in 2016 identifies majority of project delays were caused from the owner's side as compared to contractors, consultants, and other project's stakeholders. This finding matched with the research findings of the Gulf Countries Construction (GCC) Industry's literature. This study fills an important practice and research gap for improving the efficiency in delivering infrastructure projects in the holy city of Mecca and Gulf countries at large (Elawi et al., 2016). Another study done by Mahamid, I. in 2016 also conducted to investigate the performance in construction projects in Saudi Arabia in order to identify the contributors to poor performance and their severity according to public owners, contractors and consultants through a questionnaire survey. Inputs of consultant's underline that the top three affecting factors are: poor planning and scheduling, poor site management and payments delay respectively. Key project participants and researchers, could benefit from the findings and recommendations of this study. Although this study is related to views for respondents from Saudi Arabia, other developing countries could benefit from its results (Mahamid, 2016). Moreover, there several studies have the semilar result and support with above review findings accordingly (R. Hasan et al., 2014; U. Hasan, Whyte, \& Al Jassmi, 2019), (Emam et al., 2015), (Bekr, 2015),(Mohammad Saiful Islam et al., 2015).(Jarkas \& Younes, 2014), (Bierman et al., 2014), (Kamanga \& Steyn, 2013), (Albogamy et al., 2012). , (Assaf \& Al-Hejji, 2006), (Faridi \& El-Sayegh, 2006).

\section{Designed related Attributes on the Delay of the Road Construction}

Atout, M. M. in 2016 summarized literature about the Construction projects in Gulf rejoin presents particular conditions in which the consultant of the project has to concentrate during each phase of design to ensure that it will be accomplished on time, for example, the unrealistic of project duration, foreign designers and consultants, unusual growth of construction industry, the exceptional features of architectural details in the design of projects, and international consultant establishments, firms and office. Based on above literature this paper investigates the main causes of the delays contributed by the projects designers and consultants by representing their roles and responsibilities to hand over the projects on time. The outcome and the results of the study is prepared based on the designed questionnaires and interviews conducted with many consultants and designers intended to identify the causes of delays projects in Gulf region from the viewpoint of the designers (Atout, 2016). Bekr, G. A. in 2015 concluded that the most effective delay factors affecting the time overrun in the public projects in Iraq are: security measures, government change of regulations and bureaucracy, official and non-official holidays, low performance of lowest bidder contractors in the government tendering system, design and changes by owner, design changes by consultants, delay in progress payments by the owner, problems with local community, owner's lack of experience in construction and economic local and global conditions (Bekr, 2015). Emam, H., et al. in 2015 identified major changes in design during construction; ineffective planning and scheduling; ineffective control of progress, and; 
changes in the scope of projects. Construction projects need to adopt planning and scheduling methods that deal with its dynamic and changing nature to create robust programmes with buffers to deal with uncertaintie (Emam et al., 2015). Moreover, there several studies have the semilar result and support with above review findings accordingly (Bekr, 2015), (Pourrostam \& Ismail, 2012)(Alnuaimi et al., 2009) and (Toor \& Ogunlana, 2008).

\section{Client Related Attributes on the Delay of the Road Construction}

Durdyev, S., et al. in 2018 uncover the most significant factors constraining the SC in Malaysia related to government, cost, knowledge and information, workforce, and client and market (Durdyev, Ismail, Ihtiyar, Abu Bakar, \& Darko, 2018). Morever, Alamri, N., et al. in 2017 investigate and analyse the causes of delays 60 were integrated in the questionnaires which were grouped under four main categories: Client, Contractor, Consultant and External Factors. The collected data was then analysed statistically and ranked according to its significance. The results reveal, based on Pareto's law of 80/20, that the top causes behind the delays of Dam construction projects in Oman are: severe weather conditions, change orders, uncertainty in ground condition, poor site management, executive bureaucracy in client organization (Alamri et al., 2017). In the same way, Haugen, A., et al. in 2017 exlored client side as well as representatives from the design team and the main contractor. Even though the project is large and complex, the client has used design-bid-build (DBB) as project delivery method. By using this project delivery method, the client faced several challenges during the early stages of the project execution. Some of the client's challenges were shortcomings in the design, as well as lack of control of the subcontractors. By involving the contractor's knowledge in the early phase, some of the challenges could have been reduced. Since the project will not be fully implemented until the spring of 2019, the paper addresses challenges in the early execution phase of the project (Haugen, Wondimu, Lohne, \& Lædre, 2017). However, Oyegoke, A. S. and N. Al Kiyumi in 2017 identified five most frequent causes of delay in the Sultanate of Oman, in rank order, are: selection of the lowest bid, instead of best bid for the client (RII: 0.698); the financial condition of the main contractor (RII: 0.664); delay in decision-making by the client (RII: 0.656); and poor construction planning by the main contractor (RII: 0.649). Also, the findings indicate that extra cost (RII: 0.754) and project time overrun (RII: 0.724) are the most significant effects of the delay in the Oman megaprojects (Oyegoke \& Al Kiyumi, 2017). Moreover, there several studies have the semilar result and support with above review findings accordingly (Mukuka, Aigbavboa, \& Thwala, 2015), (Bekr, 2015), (Atibu Seboru, 2015), (Głuszak \& Leśniak, 2015), (Motaleb \& Kishk, 2013), (Ruqaishi \& Bashir, 2013), (Niazai \& Gidado, 2012), (Albogamy et al., 2012), (Pourrostam \& Ismail, 2012), (Rafieizonooz, 2012), ( Kaliba, Maya, \& Mumba, 2009) and (Alnuaimi et al., 2009).

\section{Manpower and Resources Related Attributes on the Delay of the Road Construction}

Durdyev, S., et al. in 2018 analyses the barriers to the adoption of the triple-bottom line of sustainability of the construction sector within the developing country of Malaysia. Findings of this paper uncover the most significant factors constraining the SC in Malaysia related to government, cost, knowledge and information, workforce, and client and market. The findings revealed that clear and effective legislative process is crucial for the enforcement of the integration of SC materials and practices as well as economics incentives which will ultimately lead to effective implementation of SC initiatives; hence, sustainable economic growth and efficient resource (energy, water and material) utilization. It is hoped that the findings provide 
guidelines for the government authorities so that they invest their efforts and allocate resources in more efficient way (Durdyev et al., 2018). Moreover, Ghisellini, P., et al. in 2018 explored the construction sector is one of the most impacting economic activities in the world. The results show that CP for C\&DWM has not been yet fully implemented in construction companies and industry mainly due to legislative and economic barriers. Construction companies are also much resistant to eco-innovation due to the fact they are only profit driven and lack of awareness of environmental protection through C\&DWM, as well as lack of culture towards sustainable development. A refining of the current C\&DWM regulations, laws and policies as well as the support of the demand of sustainable buildings are suggested as urgent measures to improve the C\&DWM by the construction companies and to put the goals of CP, CE and SC at the forefront of their business agenda (Ghisellini, Ji, Liu, \& Ulgiati, 2018).In the same way, Kong, L., et al. in 2018 studies identified issues on the supply chain management of precast construction while considering time-dependent transportation time and on-site assembly time. There are two main contributions of our work. The results also show that the objective of achieving additional environmental performance conflicts with that of obtaining economic performance. However, sensitivity analysis further shows it is not always true to consider only additional environmental performance for the suppliers to achieve 'green' value. For a sustainable business, the customer's service-JIT delivery should also be considered. The research contributes to batch delivery theory by expanding the approach to a time-dependent delivery model by considering both the economic and environmental effects (Kong, Li, Luo, Ding, \& Zhang, 2018). However, Mahamid, I. in 2017 addressed schedule delay in road construction projects in Saudi Arabia. Results indicated that the top five important factors affecting schedule delay in road construction projects are: improper planning, poor labor productivity, additional works, rework, and lack of contractor experience. The study concluded that the main effects of schedule delay in road construction projects as assessed by contractors are: cost overrun, disputes, arbitration, litigation, and poor quality (Mahamid, 2017). Moreover, there several studies have the semilar result and support with above review findings accordingly (Mohammad Saiful Islam et al., 2015), (Shah, 2014).

\section{Material and Suppliers related Attributes on the Delay of the Road Construction}

Ghisellini, P., et al. in 2018 explored the construction sector and recommend to improve its environmental performances the sector is innovating in terms of cleaner materials, products and processes (Ghisellini, Ripa, \& Ulgiati, 2018). Chen, F., et al. in 2018 investigate the structural implications and recommended that more focus should be placed on the possible measures, such as new structures and materials, to improve the structural integrity and thus the overall pavement performance of the integrated system (Chen, Coronado, Balieu, \& Kringos, 2018). However, Durdyev, S., et al. in 2018 analyses the barriers to the adoption of the triple-bottom line of sustainability of the construction sector within the developing country of Malaysia. The findings revealed that clear and effective legislative process is crucial for the enforcement of the integration of SC materials and practices as well as economics incentives which will ultimately lead to effective implementation of SC initiatives; hence, sustainable economic growth and efficient resource (energy, water and material) utilization. It is hoped that the findings provide guidelines for the government authorities so that they invest their efforts and allocate resources in more efficient way (Durdyev et al., 2018). Jiang, W., et al. in 2018 has done an extensive study on traditional and novel engineering materials and the increasing demands by growing traffic have led to tremendous changes of the function of roads. This study focused on state-ofthe-art research on the performance, applications and challenges of six environment-friendly 
functional road materials, namely the permeable asphalt concrete, noise-reducing pavement materials, low heat-absorbing pavement materials, exhaust gas-decomposing pavement materials, de-icing pavement materials, and energy harvesting pavement materials (Jiang, Huang, \& Sha, 2018).

Kong, L., et al. in 2018 studies identified issues on the supply chain management of precast construction while considering time-dependent transportation time and on-site assembly time. The optimal results show that, compared with the supplier's intuitive minimax optimization with deliveries on the earliest due date, there is an average $10.7 \%$ reduction of the objective value of a one-day assembly task by our proposed method. The results also show that the objective of achieving additional environmental performance conflicts with that of obtaining economic performance (Kong et al., 2018). However, Tarimo, M., et al. in 2017 examined construction and maintenance for the sustainable roads in Serengeti National Park. However, road construction in protected areas should be sustainable in terms of availability of quality materials within economic haulage distance and the entire construction, operation and maintenance process should have less environmental impacts like habitat fragmentation and dust pollution. The data collected were from soil material test in the existing borrow pits, traffic volume counting, document study and interview with fifty (50) road stakeholder. Results show that the current poor performance of the studied road sections may be due to lack of financial and human resources, quality gravel materials and existing traffic volume (Tarimo, Wondimu, Odeck, Lohne, \& Lædre, 2017). Moreover, Gebrehiwet, T. and H. Luo in 2017 investigates the typical causes of delay at different stages of construction and its effect in the Ethiopian construction projects. They found that the influential causes of delay investigated are corruption, unavailability of utilities at site, inflation/price increases in materials, lack of quality materials, late design and design documents, slow delivery of materials, late in approving and receiving of complete project work, poor site management and performance, late release budget/funds, and ineffective project planning and scheduling successively as unique to the Ethiopian construction project (Gebrehiwet \& Luo, 2017).

Mahamid, I. in 2016 also conducted to investigate the performance in construction projects in Saudi Arabia. Moreover, results indicate that owners rank poor communication among project participants as the top severe factor affecting the performance in construction projects, followed by poor labor productivity and poor planning and scheduling, respectively. Inputs of contractors indicate that the most severe factor is payments delay, followed by escalation of material prices and poor labor productivity, respectively(Mahamid, 2016). Moreover, there several studies have the semilar result and support with above review findings accordingly (Mukilan \& Jayanthi, 2015), (Jarkas \& Younes, 2014), (Bierman et al., 2014), (Owolabi James, Amusan Lekan, Oloke, Olusanya, \& Tunji-Olayeni, 2014), (Rahman et al., 2014), (Kamanga \& Steyn, 2013), (Haseeb, Bibi, \& Rabbani, 2011), (Pathiranage, 2011), (Jurf \& Beheiry, 2010), (Enshassi et al., 2009)(Kaliba, Muya, \& Mumba, 2009), (Al-Najjar, 2008).

\section{Material and Suppliers related Attributes on the Delay of the Road Construction}

Hamontree, C., et al. in 2018 exploed that the delay in construction project The study indicates that the 5 top factors affecting road construction delays are: incomplete drawings, lack of equipment efficiency or financial status of contractors, delay in relocating existing infrastructure structures, less of project engineer experiences, and delay in relieving environmental impact, respectively (Hamontree et al., 2018). Moreover, Bagaya, O. and J. Song in 2016 identified the top five most important delay factors were ranked as follows: financial capability of the 
contractor, financial difficulties of the owner, equipment availability of the contractor, slow payments for completed work, and poor subcontractor performance by the contractor. A comparison of the causes of schedule delays in 11 countries to validate the results of the study showed that financial capability of the contractor was not only the most encountered factor in delays for Burkina Faso's construction industry, but also appeared in many other Asian and African countries (Bagaya \& Song, 2016). However, Santoso, D. S. and S. Soeng in 2016 analyzed and summarized influencing factors on the list were land acquisition, award of project to lowest bidder, equipment breakdowns, poor site arrangement, management and supervision, unexpected ground condition and terrain, low quality of the contractor human resources, late progress payments, and low productivity of labor. Recommendations to manage the delay factors were presented. Significant relationships between the delay factors and the three project objectives also were observed and discussed (Santoso \& Soeng, 2016). Moreover, there several studies have the semilar result and support with above review findings accordingly (Shah, 2014)(Owolabi James et al., 2014)(Kamanga \& Steyn, 2013)(Mahamid, 2013)(Haseeb et al., 2011)(Kaliba et al., 2009)(Al-Najjar, 2008).

\section{Govt. regulations and laws, departmental integrations local authorization on the attributes and the Road Construction delay}

Ahmadabadi, A. A. and G. Heravi in 2019 evaluate the effects of CSFs on the success of PPP projects using PLS-SEM. The results confirmed the effect of CSF on project success and showed that private sector capability has a direct effect on project success during the construction period and government capability is very effective during the project operation stage. In addition, investigating the case studies with respect to the introduced model indicated that a transparent bidding process, risk allocation, and good partnering are among the CSFs in PPP projects in developing countries (Ahmadabadi \& Heravi, 2019). However, Mahdi, I. and E. Soliman in 2018 found about the significant and top ranked delay factors in Arabic Gulf countries. Because of most construction projects are challenged with delays which have substantially negative impacts to any country. The analysis carried out showed that fourteen delay causes are common in the gulf area. The majority of delay factors include shortages of resources, inefficiency of management teams and governmental regulation. Analysis showed that significant correlation exists between delay causes rankings in Qatar, Kuwait and KSA, while Oman is differing. This study is a contribution to the efforts required to mitigate construction industry delays in the Arabic gulf countries and other countries with similar conditions (Mahdi \& Soliman, 2018).However, Alamri, N., et al. in 2017 investigate and analyze the causes of delays in Dam projects in Oman. An intensive literature review was carried out to identify the causes of delays in Dam and infrastructure projects. The results reveal, based on Pareto's law of 80/20, that the top causes behind the delays of Dam construction projects in Oman are: severe weather conditions, change orders, uncertainty in ground condition, poor site management, executive bureaucracy in client organization, feasibility study did not cover all aspects, mistakes in soil investigation, natural effects during construction work, difficulty of defining project requirement, slowness of decision making process, delay of obtaining approval from the different government authorities, and land acquisition (Alamri et al., 2017). Moreover, there several studies have the semilar result and support with above review findings accordingly (Atibu Seboru, 2015), (Alzebdeh et al., 2015), (Bekr, 2015) and (Kaliba et al., 2009). 


\section{CONCLUSION AND RECOMMENDATIONS}

The prime aims of the study to investigates of empirical articles and reviewed on the moderating effects of the regulations, integrations of works and local authorization on the attributes of critical success factors and constructions delay of the road projects in Oman. The present study summarized and short listed of the factors of the consultant related factors, the contractor related factors, designed related factors, client related factors, labor related factors, material related issues, equipment related issues respectively. Moreover, study also summarized that there are moderating effects of the regulations, integrations of works and local authorization on the attributes of critical success factors and constructions delay of the road projects in Oman. Especially, the consultant related factors are effects on the delay of projects, in case of delaying of approval, inaccurate site investigations and delay inspections, inadequate project management assistance, poor of experiences, late reviewing and approval of design, poor communications and coordination's and conflicting consultant vs. design engineer respectively. Moreover, the contractor related factors also revealed to cause to delay of road projects by delaying of payment, insufficient projects planning and scheduling, inadequate experiences contractors, poor site management and supervisions, incompetent project team, inappropriate constructions methods, obsolete technology, unreliable subcontractors, frequent changes of subcontractors, poor communications and coordination's with other parties and rework due to errors accordingly. On the other hand, designed related factors are also caused to delay road projects by insufficient data collections and survey before design, design errors, mistakes and delay in producing of design documents, poor use of advanced engineering software, complexity of project design, unclear and inadequate details in design drawing and misunderstand of client requirements by designer accordingly.

In the same way, labor related factors are also caused to delay of project by low productivity of labor, unqualified and inadequate experiences, low motivation and moral, shortages of labor, absenteeism, slow mobilizations labor, labor sticks and personal conflicts among labor respectively. However, in case of material related issues also identified which has caused to delay road constructions by poor of reliable supplier, escalations of martials prices, poor quality of constructions materials, late delivery of materials, shortage of constructions materials, poor procurement of constructions materials, changes of materials types and specifications and damage of materials etc. Similarly, equipment related issues are considered to find the caused to delay of road constructions by inadequate modern equipment's, low efficiency of equipment's, shortage of equipment, slow mobilizations of equipment, frequent equipment breakdown, equipment allocations problem and improper equipment respectively.

The study also summarized on about the natural disaster (flood, hurricanes and cyclone etc.), conflict, war, global financial crisis, compensation delay to affected property owner, price fluctuated, unexpected ground conditions (soil and high-water level), changing of government regulations and laws, delays in obtaining permission from municipality, loss of time by traffic control and restrictions at job site, problem with inhabitant of community, delays in providing service from utilities (water and electricity's) and accident during constructions respectively. The present study also concluded the effects of above factors which have delay road constructions through increasing of cost and overrun it, taken overtime, creating of disputes, going for lawsuits, finally happing of abandon of projects. Therefore, the present study taken initiatives to evaluate the current status delay level of the constructions of road as well as also will identify the critical success factors especially the contactor, owner, consulted, designed, client, manpower and resources, material and suppliers and equipment related attributes caused delay of 
constructions of road in Oman. Furthermore, study also will fill-up literature gap by applying of government regulations, departmental integrations of works and local authorization weather there is moderating effects of the on the attributes of critical success factors and constructions delay of the road projects in Oman. The present study recommends doing a conclusive investigation on the above literature gap by real data and justifying above review relationship of moderating effects of the regulations, integrations of works and local authorization on the attributes of critical success factors and constructions delay of the road projects in Oman.

\section{REFERENCES}

Abdel Khalek, H. A., Aziz, R. F., \& Abdeen, A. H. (2018). Identify and prioritize the major influencing causes of automated concrete mixing system for mega construction projects using analytic hierarchy process. Alexandria Engineering Journal, 57(4), 3451-3461. https://doi.org/10.1016/j.aej.2018.04.003

Ahmadabadi, A. A., \& Heravi, G. (2019). The effect of critical success factors on project success in Public-Private Partnership projects: A case study of highway projects in Iran. Transport Policy, 73, 152-161. https://doi.org/10.1016/j.tranpol.2018.07.004

Al-Najjar, J. M. (2008). Factors influencing time and cost overruns on construction projects in the Gaza Strip. Factors Influencing Time and Cost Overruns on Construction Projects in the Gaza Strip.

Alamri, N., Amoudi, O., \& Njie, G. (2017). Analysis of construction delay causes in dams projects in Oman. European Journal of Business and Social Sciences, 6(2), 19-42.

Albogamy, A., Scott, D., \& Dawood, N. (2012). Addressing construction delays in the Kingdom of Saudi Arabia. International Proceedings of Economics Development \& Research, 45, 148-153.

Alnuaimi, A. S., \& Mohsin, M. (2013). Causes of delay in completion of construction projects in Oman. Paper presented at the International Conference on Innovations in Engineering and Technology.

Alnuaimi, A. S., Taha, R. A., Al Mohsin, M., \& Al-Harthi, A. S. (2009). Causes, effects, benefits, and remedies of change orders on public construction projects in Oman. Journal of construction engineering and management, 136(5), 615-622.

Alzebdeh, K., Bashir, H., \& Al Siyabi, S. (2015). Applying interpretive structural modeling to cost overruns in construction projects in the sultanate of Oman. The Journal of Engineering Research [TJER], 12(1), 53-68.

Assaf, S. A., \& Al-Hejji, S. (2006). Causes of delay in large construction projects. International Journal of Project Management, 24(4), 349-357. 
Atibu Seboru, M. (2015). An Investigation into Factors Causing Delays in Road Construction Projects in Kenya. American Journal of Civil Engineering, 3(3), 51. https://doi.org/10.11648/j.ajce.20150303.11

Atout, M. M. (2016). Delays caused by project consultants and designers in construction projects. International Journal of Structural and Civil Engineering Research, 5.

Aziz, R. F., \& Abdel-Hakam, A. A. (2016). Exploring delay causes of road construction projects in Egypt. Alexandria Engineering Journal, 55(2), 1515-1539. https://doi.org/10.1016/j.aej.2016.03.006

Bagaya, O., \& Song, J. (2016). Empirical study of factors influencing schedule delays of public construction projects in Burkina Faso. Journal of Management in Engineering, 32(5), 05016014.

Bekr, G. A. (2015). Causes of delay in public construction projects in Iraq. Jordan Journal of Civil Engineering, 159(3091), 1-14.

Bierman, B., O’donnell, J., Burke, R., McCormick, M., \& Lindsay, W. (2014). Construction of an enclosed trough EOR system in South Oman. Energy Procedia, 49, 1756-1765.

Chen, F., Coronado, C. F., Balieu, R., \& Kringos, N. (2018). Structural performance of electrified roads: A computational analysis. Journal of Cleaner Production, 195, 13381349. https://doi.org/10.1016/j.jclepro.2018.05.273

Cristóba, J. R. S. (2014). Cost Allocation between Activities that have Caused Delays in a Project Using Game Theory. Procedia Technology, 16, 1017-1026. https://doi.org/10.1016/j.protcy.2014.10.056

Durdyev, S., Ismail, S., Ihtiyar, A., Abu Bakar, N. F. S., \& Darko, A. (2018). A partial least squares structural equation modeling (PLS-SEM) of barriers to sustainable construction in Malaysia. Journal of Cleaner Production, 204, 564-572. https://doi.org/10.1016/j.jclepro.2018.08.304

Elawi, G. S. A., Algahtany, M., \& Kashiwagi, D. (2016). Owners' Perspective of Factors Contributing to Project Delay: Case Studies of Road and Bridge Projects in Saudi Arabia. Procedia Engineering, 145, 1402-1409. https://doi.org/10.1016/j.proeng.2016.04.176

Emam, H., Farrell, P., \& Abdelaal, M. (2015). Causes of delay on infrastructure projects in Qatar. Paper presented at the Proceedings of the 31st Annual ARCOM Conference, Lincoln, UK, Association of Researchers in Construction Management, Nottingham, UK.

Enshassi, A., Al-Najjar, J., \& Kumaraswamy, M. (2009). Delays and cost overruns in the construction projects in the Gaza Strip. Journal of Financial Management of Property and Construction, 14(2), 126-151. 
Faridi, A. S., \& El-Sayegh, S. M. (2006). Significant factors causing delay in the UAE construction industry. Construction Management and Economics, 24(11), 1167-1176.

Gebrehiwet, T., \& Luo, H. (2017). Analysis of Delay Impact on Construction Project Based on RII and Correlation Coefficient: Empirical Study. Procedia Engineering, 196, 366-374. https://doi.org/10.1016/j.proeng.2017.07.212

Ghisellini, P., Ji, X., Liu, G., \& Ulgiati, S. (2018). Evaluating the transition towards cleaner production in the construction and demolition sector of China: A review. Journal of Cleaner Production, 195, 418-434. https://doi.org/10.1016/j.jclepro.2018.05.084

Ghisellini, P., Ripa, M., \& Ulgiati, S. (2018). Exploring environmental and economic costs and benefits of a circular economy approach to the construction and demolition sector. A literature review. Journal of Cleaner Production, 178, 618-643. https://doi.org/10.1016/j.jclepro.2017.11.207

Głuszak, M., \& Leśniak, A. (2015). Construction Delays in Clients Opinion - Multivariate Statistical Analysis. Procedia Engineering, 123, 182-189. https://doi.org/10.1016/j.proeng.2015.10.075

Guida, P. L., \& Sacco, G. (2019). A method for project schedule delay analysis. Computers \& Industrial Engineering, 128, 346-357. https://doi.org/10.1016/j.cie.2018.12.046

Hamontree, C., Thapanont, P., Santi, C., \& Pruethipong, X. (2018). Causes of delay on highway construction projects in Thailand. MATEC Web of Conferences, 192, 02014. https://doi.org/10.1051/matecconf/201819202014

Hasan, R., Suliman, S. M., \& Malki, Y. A. (2014). An investigation into the delays in road projects in Bahrain. International Journal of Research in Engineering and Science, 2(2), $38-47$.

Hasan, U., Whyte, A., \& Al Jassmi, H. (2019). Critical review and methodological issues in integrated life-cycle analysis on road networks. Journal of Cleaner Production, 206, 541558. https://doi.org/10.1016/j.jclepro.2018.09.148

Haseeb, M., Bibi, A., \& Rabbani, W. (2011). Problems of projects and effects of delays in the construction industry of Pakistan. Australian journal of business and management research, 1(5), 41-50.

Haugen, A., Wondimu, P. A., Lohne, J., \& Lædre, O. (2017). Project Delivery Methods in Large Public Road Projects - A Case Study of E6 Jaktøyen - Sentervegen. Procedia Engineering, 196, 391-398. https://doi.org/10.1016/j.proeng.2017.07.215

Islam, M. S., \& Trigunarsyah, B. (2017). Construction delays in developing countries: a review. Journal of Construction Engineering and Project Management, 7(1), 1-12. 
Islam, M. S., Trigunarsyah, B., Hassanain, M., \& Assaf, S. (2015). Causes of delay in construction projects in Bangladesh. Paper presented at the The 6th International Conference on Construction Engineering and Project Management, Busan, Korea.

Jarkas, A. M., \& Younes, J. H. (2014). Principle factors contributing to construction delays in the State of Qatar. International Journal of Construction Project Management, 6(1), 39.

Jiang, W., Huang, Y., \& Sha, A. (2018). A review of eco-friendly functional road materials. Construction and Building Materials, 191, 1082-1092. https://doi.org/10.1016/j.conbuildmat.2018.10.082

Jurf, N. A., \& Beheiry, S. (2010, 30 March-1 April 2010). Qatar residential construction projects. Paper presented at the 2010 Second International Conference on Engineering System Management and Applications.

Kaliba, C., Muya, M., \& Mumba, K. (2009). Cost escalation and schedule delays in road construction projects in Zambia. International Journal of Project Management, 27(5), $522-531$.

Kamanga, M., \& Steyn, W. (2013). Causes of delay in road construction projects in Malawi. Journal of the South African Institution of Civil Engineering, 55(3), 79-85.

Kong, L., Li, H., Luo, H., Ding, L., \& Zhang, X. (2018). Sustainable performance of just-in-time (JIT) management in time-dependent batch delivery scheduling of precast construction. $\begin{array}{lllll}\text { Journal of Cleaner } \quad \text { Production, 193, } & \text { 684-701. }\end{array}$ https://doi.org/10.1016/j.jclepro.2018.05.037

Mahamid, I. (2013). Contributors to schedule delays in public construction projects in Saudi Arabia: owners' perspective. Journal of Construction Project Management and Innovation, 3(2), 608-619.

Mahamid, I. (2016). Factors contributing to poor performance in construction projects: studies of Saudi Arabia. Australian Journal of Multi-Disciplinary Engineering, 12(1), 27-38. https://doi.org/10.1080/14488388.2016.1243034

Mahamid, I. (2017). Schedule delay in Saudi Arabia road construction projects: size, estimate, determinants and effects. Int J Arch Eng Constr, 6(3), 51-58.

Mahdi, I., \& Soliman, E. (2018). Significant and top ranked delay factors in Arabic Gulf countries. International Journal of Construction Management, 1-14. https://doi.org/10.1080/15623599.2018.1512029

Motaleb, O., \& Kishk, M. (2013). An investigation into the risk of construction projects delays in the UAE. International Journal of Information Technology Project Management (IJITPM), 4(3), 50-65. 
Mukilan, K., \& Jayanthi, R. (2015). Severity Rating Of Time And Cost Overrun In Construction Projects.

Mukuka, M., Aigbavboa, C., \& Thwala, W. (2015). Effects of Construction Projects Schedule Overruns: A Case of the Gauteng Province, South Africa. Procedia Manufacturing, 3, 1690-1695. https://doi.org/10.1016/j.promfg.2015.07.989

Niazai, G. A., \& Gidado, K. (2012). Causes of project delay in the construction industry in Afghanistan. Proceedings of the EPPM.

Owolabi James, D., Amusan Lekan, M., Oloke, C., Olusanya, O., \& Tunji-Olayeni, P. (2014). CAUSES AND EFFECT OF DELAY ON PROJECT CONSTRUCTION DELIVERY TIME. IJER April.

Oyegoke, A. S., \& Al Kiyumi, N. (2017). The causes, impacts and mitigations of delay in megaprojects in the Sultanate of Oman. Journal of Financial Management of Property and Construction, 22(3), 286-302.

Pathiranage, Y. L. (2011). Factors influencing the duration of road construction projects in Sri Lanka.

Pourrostam, T., \& Ismail, A. (2012). Causes and effects of delay in Iranian construction projects. International Journal of Engineering and Technology, 4(5), 598.

Rafieizonooz, M. (2012). Minimizing Delay in Construction Projects in Tehran, Iran. Universiti Teknologi Malaysia.

Rahman, M., Lee, Y. D., \& Ha, D. K. (2014). Investigating main causes for schedule delay in construction projects in Bangladesh. Journal of Construction Engineering and Project Management, 4(3), 33-46.

Ruqaishi, M., \& Bashir, H. A. (2013). Causes of delay in construction projects in the oil and gas industry in the gulf cooperation council countries: a case study. Journal of Management in Engineering, 31(3), 05014017.

Santoso, D. S., \& Soeng, S. (2016). Analyzing delays of road construction projects in Cambodia: Causes and effects. Journal of Management in Engineering, 32(6), 05016020.

Shah, R. K. (2014). A new approach for automation of location-based earthwork scheduling in road construction projects. Automation in Construction, 43, 156-169. https://doi.org/10.1016/j.autcon.2014.03.003

Shah, R. K. (2016). An Exploration of Causes for Delay and Cost Overruns In Construction Projects: Case Study of Australia, Malaysia \& Ghana. Journal of Advanced College of Engineering and Management, 2(1). 
Sweis, G., Sweis, R., Abu Hammad, A., \& Shboul, A. (2008). Delays in construction projects: The case of Jordan. International Journal of Project Management, 26(6), 665-674. https://doi.org/10.1016/j.ijproman.2007.09.009

Tarimo, M., Wondimu, P., Odeck, J., Lohne, J., \& Lædre, O. (2017). Sustainable roads in Serengeti National Park: - gravel roads construction and maintenance. Procedia Computer Science, 121, 329-336. https://doi.org/10.1016/j.procs.2017.11.045

Toor, S. U. R., \& Ogunlana, S. O. (2008). Problems causing delays in major construction projects in Thailand. Construction Management and Economics, 26(4), 395-408.

\section{Copyrights}

Copyright for this article is retained by the author(s), with first publication rights granted to the journal. This is an open-access article distributed under the terms and conditions of the Creative Commons Attribution license (http://creativecommons.org/licenses/by/4.0/) 